\title{
"LA DESTREZZA DI GUARDARE OLTRE": CLOSE-UP ON THE REPRESENTATION OF WOMEN IN SILVIO SOLDINI'S LE ACROBATE AND PANE E TULIPANI
}

\section{Susanna Scarparo and Mariateresa Tufano}

\begin{abstract}
Sommario
Questo saggio analizza il modo in cui Silvio Soldini rappresenta la donna nei film Le acrobate (1997) e Pane e tulipani (2000). II modo in cui i personaggi femminili vengono rappresentati in questi due film si distingue rispetto ad altri esempi tratti dalla storia del cinema italiano soprattutto per il modo in cui Soldini tratta i rapporti tra donne, che diventano anche un modo di orientarsi diverso per comprendere se stessi ed il mondo. Tali rapporti si richiamano alla pratica dell'affidamento (o delle relazioni) proposta dalla Libreria delle Donne di Milano.
\end{abstract}

Following Fellini's death in 1994, "people were really mourning the virtual death of Italian cinema" (Singer quoted in Marcus, 2002:3). Since then, however, a number of critics have celebrated the emergence of a 'new Italian cinema.' According to Manuela Gieri, this 'new' cinema began in the late 70s and peaked under directors such as Nanni Moretti, Gianni Amelio, Gabriele Salvatores, Maurizio Nichetti and to some extent Silvio Soldini. By 'new', Gieri refers to "a cinema that decisively freed itself from the burden of imitation and the anxiety of influence in relation to the grand cinema of the 1940s, 1950s, and 1960s in its neorealistic, and 
later auteuristic and generic expressions" (1999:5) and "attempts to reflect and comment upon a society in rapid change" (Gieri, 1995:225).

While Soldini adheres to this general description of the 'new Italian cinema,' the 'new' element of Soldini's films that we will focus on in this article is his radically different representation of female characters. Italian cinema has a long and established tradition of presenting women as objects of male desire. Accordingly Marcia Landy points out that, "women occupy a precarious position in the Italian cinema, both as filmmakers and as subjects of works by male filmmakers" (2000:261). In contrast to the traditional representations of women in Italian cinema, Soldini's cinema highlights the way in which relationships between women can offer an alternative understanding of the world and of oneself in the world. By positioning women at the heart of his cinema, Soldini presents women as subjects of their own stories. Two constant features of Soldini's cinema are: the role played by women as central characters of his films and the use of the journey motif as generally motivated by what we call 'la casoalità soldiniana'. By 'casoalità' we refer to the way in which Soldini foregrounds internal journeys without turning such journeys into spectacular events, and the way in which events just seem to happen by chance. In this article, we discuss these characteristics of Soldini's work by focusing primarily on the representation of his female characters in two of his films, Le acrobate (1997) and Pane e tulipani (2000). ${ }^{1}$

Soldini studied for two years in the United States, at the New York University, and upon his return to Italy became an established member of the independent Milanese cinema scene. His first feature-length film L'aria serena dell'ovest (1990) was followed by Un'anima divisa in due (1993) and Le acrobate (1997). However, it is with Pane e tulipani (2000) that Soldini received international recognition from both the critics and the general public. After Pane e tulipani, he 


\section{Soldini’s Casoalità}

The motif of the journey can be traced in Soldini's cinema from his first feature length film, L'aria serena dell'ovest, to his latest, Agata e la tempesta. While in the earliest film the geographic movement focuses on the movement within a single urban setting, later films criss-cross the Italian peninsula at times extending beyond its borders, as the geographical journey becomes a metaphor for the figurative one.

In Soldini's films, the journey is not so much a question of physical movement as of emotional transformation and self-discovery. As Soldini explains:

The journey still represents, in any case, a time for reflection and discovery. A time in which you are assailed by new images, producing new emotions which you could never have known had you stayed at home (Interview in Ferrucci, 2000:19). ${ }^{2}$

Although the journey in his films allows for change, its function is not entirely in accordance with the conventions of the road movie. ${ }^{3}$ In Soldini's films, the journey is never linear and its purpose is never entirely

made Brucio nel vento (2001), which is an adaptation of the novel Ieri by Agota Kristof, and Agata e la tempesta (2004).

"Il viaggio è sempre comunque un momento di riflessione e di scoperta. Un momento in cui nuove immagini ti invadono e ti provocano emozioni che non avresti potuto conoscere restando fermo, a casa." Unless otherwise stated, all translations from the Italian are by Denise Formica.

3 For discussions of the road movie see David Laderman, 2002, Kerstin Pilz, 2003 and Laura Riscaroli, 2003. 
clear either to the protagonists or the viewers. Indeed the journey and the journeying seem to gain a momentum of their own. For example, in $L e$ acrobate, Elena, attempting to establish a connection with other women who had known her late and enigmatic friend, Anita, travels from Treviso to the southern city of Taranto, looking for Maria and her daughter Teresa. Following Elena's journey, Maria and Teresa also secretly travel to Treviso to visit Elena and, prompted by Teresa's desire to see the 'North' with its famous mountains, the three women travel together to the summit of Mont Blanc. In Pane e tulipani, it is only because Rosalba, a housewife from Pescara is left behind at a petrol station while travelling with her family on an organised bus tour, that she ends up embarking on a journey. Rather than waiting for the bus to come back, she makes a sudden decision to accept a lift, eventually arriving in Venice, where she starts a new life. So the protagonist is often unaware or not quite conscious of what motivates her to embark on her journey. As Soldini explains when discussing Le acrobate:

The idea was that these two women be somehow pushed by these small episodes into listening to their internal voices, and to their irrational moments and allowing themselves to be carried away to an unknown place that no longer had anything to do with their plans or their everyday life. (cited in Audino and Medosi 2000:61)

This movement to an unknown location represents a metaphorical as well as a geographical journey. It allows Elena, Teresa and Maria (in Le

4 "L'idea era che queste due donne fossero in qualche modo spinte da queste piccole apparizioni a dare ascolto a delle voci interiori, a dei momenti di irrazionalità, a lasciarsi trasportare in un territorio a loro sconosciuto, che non ha più a che fare con una progettualità, con una quotidianità." 
acrobate) as well as Rosalba and Grazia (in Pane e tulipani) the freedom to forge new relationships with each other. These relationships enable them to create new identities and in Rosalba's case, a new life. It is the protagonists' mobility which allows the development of the journey's potential to "develop the relationships between the characters" (cited in Audino and Medosi 2000:19), and which is closely linked to what Rosi Braidotti calls "nomadic shifts" (1994:6). According to Braidotti, nomadic shifts designate "a creative sort of becoming; a performative metaphor that allows for otherwise unlikely encounters and unsuspected sources of interaction of experience and knowledge" (1994:6). The opportunities, the meetings, the revelations and discoveries that befall the character during the journey allow for a personal re-birth.

Soldini, however, facilitates the nomadic state by his very distinctive use of chance (casoalità). These chance happenings, (or what we call casoalità soldiniana) in Soldini's films are never presented as exceptional, but rather as coincidences that can happen to anyone and therefore appear almost mundane. Yet, in both films, these chance occurrences lead the female protagonists to encounters with women very different from themselves. These 'different' women provide access to something otherwise not encountered in everyday life but which the use of chance renders accessible and possible for the protagonists. These new possibilities are visually communicated by the countless opening and closing of windows and doors. Windows in particular allude to the existence of alternative possibilities while doors symbolise how these possibilities can either be rejected or embraced. As such, windows and doors also establish borders between public and private spheres, between outside and inside, external and internal realities (Canova, 1999:62). 
Soldini uses the opening and closing of windows and doors to allude to the delicate balance (bilico) in which his female characters find themselves, oscillating between the adherence to daily routine dictated by their public image and the wish to explore and act on their intimate and personal desires. Hence the title Le acrobate, which refers explicitly to the many acrobatic feats Elena, Maria and Teresa are required to perform in order to maintain a balance between the duties associated with their public roles and their own desires from within. Pane e tulipani also refers to Rosalba's dilemma, caught as she is between doing what she ought to do and fulfilling her dreams. Rosalba eventually follows her dreams and transforms herself from a duty-bound housewife into a satisfied lover of a romantic knight and an accordion player. However, the presence of her son, Nic, in the closing scene where all dance to the sound of Rosalba and her lover's music, suggests she does not relinquish her role as mother completely but continues to balance her different roles.

An example of Soldini's use of windows can best be seen in the scene in which Rosalba, while waiting at the petrol station, looks out a large window onto the road beyond. This medium shot of Rosalba, facing the window and looking at the cars going in opposite directions, foregrounds her feelings of invisibility as she realizes that the others, including her own family 'mica s'accorgono' ('are unlikely to realise') that she is not on the bus with them. On the one hand, we are made aware that Rosalba feels like an object, always there and taken for granted. On the other hand, we recognize her desire to choose her own path, or at least her hankering for the possibility to go her own way, even if only for a brief holiday. This seemingly inconsequential shot of cars travelling in opposite directions shows that Rosalba is now called upon to choose which way to go. The fact that she looks down on the cars from upstairs is significant in that it 
shows that Rosalba — albeit unwittingly — has some control over her life.

The window here presents her with the opportunity to take a chance and foregrounds a later scene in which Rosalba, behind the wheel and looking through the car window, decides to take the road to Venice. She is now a driver rather than a passenger (forgotten by her family) on a chartered bus. By becoming a driver and choosing to take the road to Venice, Rosalba realizes the potential to take control of her life which she had previously glimpsed at through the petrol station window. Both shots are followed by a close-up of Rosalba's face. In the first instance, she appears surprised to hear herself being paged over the loud speaker as she is summoned to the phone, whereas in the latter shot, the close-up focuses on a smiling Rosalba, happy to have made her choice to go to Venice for no other reason than that she has never been there before.

\section{Between Women}

As a typically male genre, the American road movie uses the car as a symbol of freedom, power, strength, and speed. David Laderman contrasts this to the European road movie which "foregrounds the meaning of the quest journey more than the mode of transport": it follows that "revelation and realization receive more focus than the act of driving" (2002: 248). In both cases, however, typically the road movie functions within a male universe, which disregards the notion of sexual difference.

\section{As Adriana Cavarero argues:}

To conceive of sexual difference beginning from universal man means to conceive of it as already thought of, in other 
words, to conceive of it through the agency of an idea which is based on the non-conception of the very difference. $(1987: 48)^{5}$

The notion of sexual difference is central to the representation of women in both Le acrobate and Pane e tulipani. It is interesting to note that in an interview Soldini states: "I am very interested in women perhaps because they are different to me." (Malanga, 1998:28). ${ }^{6}$

Soldini often uses close-up shots in both films to focus specifically on his female protagonists as subjects rather than objects of the narrative. Such a representation, however, differs considerably from the representation of options opened to women in road movies such as, for instance, Thelma and Louise, in which the female characters look for a utopian escape that can only culminate in death. Like Rosalba, Thelma is a housewife, but unlike her Italian counterpart, she is paralysed by her subordination to male power and is clearly marked as 'Other' to man and, therefore, inferior to him. By contrast, Rosalba is presented as different from, rather than as 'Other' to, man and her difference is never equated with inferiority.

By giving female characters central roles in most of his films, Soldini also deviates considerably from the tradition of Italian cinema in which women are mainly presented as objects of male desire and are cast mainly as femme fatale, mothers, daughters, wives, entertainers or prostitutes.

\footnotetext{
5 "Pensare la differenza sessuale a partire dall'universale uomo significa pensarla come già pensata, ossia pensarla attraverso le categorie di un pensiero che si regge sul non pensamento della differenza stessa."

6 " $[. .$.$] le donne mi interessano molto forse perché sono diverse da me."$
} 
Their roles and characterisation usually depend on their relationship to the male protagonist. ${ }^{7}$ As late as 2000 , we still find characters such as Malèna, in the eponymous film by Giuseppe Tornatore. Throughout the entire film, she hardly says a word and seems to exist merely to be looked at and to awaken the young Renato's sexual fantasies. The film frames and represents her through what Laura Mulvey has called "the gaze of man" (1988:67). Like many other female characters before and after her in the tradition of Italian cinema, Malèna is a "bearer of meaning, not maker of meaning" (to borrow Mulvey's expression, 58). According to Mulvey, this is due to the fact that:

In a world ordered by sexual imbalance, pleasure in looking has been split between active/male and passive/female. The determining male gaze projects its phantasy on to the female figure which is styled accordingly. In their traditional exhibitionist role women are simultaneously looked at and displayed, with their appearance coded for strong visual and erotic impact so that they can be said to connote to-belooked-at-ness. (Emphasis in the original. 1988:62)

By contrast, in Soldini's films, particularly the two under discussion in this article, women not only resist the male gaze and its connotations of 'to-be-looked-at-ness', but are also central to the narrative as makers of meaning. The kind of meaning they make is twofold. First, they give voice to the underlying sense of unease and inadequacy women often feel in social relationships, and secondly they embark on their journeys,

7 Di Nicola, by contrast, argues that female characters are becoming more prominent and better developed in contemporary European cinema (1998:109-46). For discussions on women's representation in, and contribution to, Italian cinema see Carrano (1977); Frabotta (1980); Bruno and Nadotti (1988); Grignaffini_(2002). 
become nomads and take advantage of coincidences in order to achieve freedom. This freedom is to be distinguished from emancipation, which places women "into a social game with words and desires" which are not theirs (Milan Women's Bookshop Collective, 1983:7). It is rather, as Ida Dominijanni describes it, "a freedom in deed and practice, an event which is manifested and renewed each time it modifies the social and symbolic order, shifting power relations or opening up spaces of meaning and significance" (2003:4). It is a freedom obtained through the modification of oneself and one's understanding of the world. However, this change cannot take place in isolation, but only through interacting with other women.

Indeed, in Le acrobate and Pane e Tulipani, the protagonists' choices are always inspired or instigated by other women. In Le acrobate, it is Anita, the old woman Elena knocks down with her car by chance, who moves Elena in ways she cannot quite comprehend. She is instinctively drawn to this very different woman, who migrated to Italy from Bulgaria, lives in poverty and ostensibly has nothing in common with her. Elena's seemingly inexplicable attraction towards Anita takes her to Taranto where she meets Maria and her daughter Teresa, who had also met Anita by chance on a boat from Greece. As Bernadette Luciano points out, "in interweaving the lives of these characters, Soldini performs a sort of acrobacy of his own" (2002:342) as he constructs a series of parallel sequences which link the women's lives.

Elena is a chemist and works in a managerial role for a cosmetics factory. Maria works in a supermarket, where we see her shelving cosmetics. Her daughter, Teresa, has just lost her first tooth and has a passion for 
chemistry. What these women share are "piccole cose" ("small things") but also "piccoli spostamenti" ("small shifts"). ${ }^{8}$ Their experiences are linked by similar gestures: crying and rinsing their faces, stopping to look at mannequins through shop-windows, and unfulfilling relationships with their respective husband and lover. Their subsequent meeting and journey to Mont Blanc changes their lives in small yet profound ways. Elena and Maria find in each other, and through their relationship, the possibility for a different way of life. Through their shared passion for chemistry, Teresa finds in Elena a symbolic mother (Luciano, 2002:342) capable of offering both a glimpse of, and access to, a world which was previously closed to her. Elena's laboratory at the cosmetics factory, where she takes Teresa, is symbolic of this world.

In Pane e tulipani, Rosalba is inspired towards change by the eccentric woman she meets while waiting at the petrol station. Given their radically different lives, this woman represents un'altra-da-sè for Rosalba who tells her she married at twenty one, only to hear the other claim that at the same age she was 'a Copenhagen facendo il mio secondo aborto.' ('In Copenhagen, having my second abortion'). The brief meeting with this woman prepares Rosalba for her friendship with the holistic and new-age masseuse, Grazia, who mediates Rosalba's entrance into her new social reality. Their relationship is instrumental in helping Rosalba change her life and accept Fernando's love.

Significantly, the relationships between Grazia and Rosalba, Elena and Anita, Elena and Teresa, or Elena and Maria, are not founded on feelings of solidarity, but rather on the recognition of disparity and difference and

Soldini used these words to discuss what happens in his films. See Luciano, 2002:341. 
the attribution of value to such difference. This is reminiscent of the theoretical and political practice of affidamento (entrustment), later renamed la pratica delle relazioni (the practice of relationships), developed by the Milan Women's Bookshop Collective. ${ }^{9}$ This practice was first introduced and discussed in the 1983 essay Più donne che uomini, also known as the green Sottosopra. It was motivated by a desire to offset the estrangement felt by women in social relations by attributing value to 'that ancient relationship' with the mother:

The relationship between mother and daughter has no form in patriarchal society; it is therefore conflictual and mother and daughters are both losers. We have come to understand that we engage with disparities between women in our political practice and that this is precious. To recognise that someone like us has 'something extra' breaks the rule of male society according to which, once the mother is removed, all women are definitely equal [. . .]. The recognition of disparities between women is [. . .] not an end in itself. It is the practice of a contradiction, a practice which is needed to allow freedom from fear of being less than other women and through which each woman can arrive at a sense of her own value because she can rely on what is valuable in others, and treat it as an element of strength. (1983:14)

The recognition that another woman has 'something extra' fuels one's desire to enter into a relationship of 'entrustment' with that woman. It is important to clarify that this 'something extra' does not relate to

The term 'theoretical practice' has been defined as "the intervention of theories within concrete practices, and the restructuring of theory by the imperatives of experience and practice" (see Cicioni 81). 
institutional power and is not dependent on the logics of power or ownership. It is rather, something to do with the every essence of one's being. Affidamento, then, can be described as "il stare nel mondo attraverso la mediazione di un'altra donna" ("being in the world through the mediation of another woman") (Diotima, 1987:153).

One example of this can be seen in Le acrobate, when Elena and Anita bury Anita's cat, Zaccaria. At this point in the narrative, the viewer is aware of Elena's discomfort and her unease with her way of being in the world. Sensing that Anita has this 'something extra', she agrees to take time off from work to drive her 'fuori città, lontano dalle case' ('out of the city, away from the houses') to find a suitable location for Zaccaria's burial. Anita guides them to a place under a tree and they dig a hole for the cat. Significantly, whereas Anita digs with a spoon, "a domestic implement of nurturing" (Luciano, 2002:347), Elena uses a car jack, which symbolically links her to the phallogocentric world in which she is successful but from which she feels estranged. Anita's choice to dig under a tree evokes Deleuze and Guattari's notion of the 'rhizome', a root that grows underground which, according to Braidotti, stands for "a nonphallogocentric way of thinking: secret, lateral, spreading, as opposed to the visible, vertical ramifications of Western trees of knowledge" (Braidotti, 1994:23). This way of thinking is precisely the "something extra' Elena recognizes in Anita.

This scene, therefore, abounds with literal and symbolic references to notions of re-birth and regeneration. The long shot of the countryside following a medium shot of Anita and Elena on their knees, juxtaposes nature with humanity. Three quarters of the mise en scène are occupied by the green landscape, sky and distant trees. The tree trunk under which the two women bury Zaccaria is the only detail which is clearly in focus. All 
of a sudden, however, Anita and Elena stand up, taking a central place within the mise en scène, almost as if, like trees, they had also grown out of the earth. They are filmed from behind as they rise from the ground, but a cut to a close up of their faces shows them as if re-born from the earth. This is particularly so for Elena, who occupies most of the frame as she stands behind Anita, helping her symbolic mother to rise.

Following this moment of re-birth, Elena embarks on a modification of herself which eventually leads to her relationship with Maria and Teresa. As Luisa Muraro writes, "we have our origins in a separation full of uncertainties and promises: a beginning, our birth, which deprives us of the security of our mother's body in order to hand us over to the precariousness of human relationships, beginning with our own mothers" (1996:14). ${ }^{10}$

Alluding to the notion of re-generation, a close-up of Anita's hands shows her taking an apple from her pockets: she divides the fruit in halves and gives one piece to Elena. The sharing of the apple, "a fruit that symbolically links all women" (Luciano, 2002:347), serves to recognize that a life-changing event has taken place and to seal the relationship of affidamento between the two women. Female a cappella voices embody the internal voices that make Elena follow Anita: she listens to these voices and allows herself to trust Anita. It is through this relationship that Elena learns la pratica del partire da sé (the practice of beginning from oneself). According to Chiara Zamboni this practice is:

10 "Noi abbiamo origine da un distacco pieno di incognite e promesse: un inizio, la nascita, che ci fa perdere la sicurezza del corpo materno per affidarci alla precarietà dei rapporti umani, a cominciare dalla donna che ci è madre." 
a wisdom that is lacking in some, so much so that they end up trying to control the small part of the world which they inhabit with rules and regulations. They, therefore, forget the links that each one has with him/herself, with others, with work and with our own surroundings. $(1996: 1)^{11}$

Elena begins this practice when she leaves that 'small part of the world' made up primarily of her job as a chemist and of all the "rules and regulations" in order to go to Taranto where she meets Maria and Teresa.

Difference is also central to the affidamento (or pratica delle relazioni) between Rosalba and Grazia in Pane e tulipani. Their relationship is symbolised by the bindi they put on their foreheads while watching a film together. The bindi is emblematic of Grazia's alternative life style and represents that 'something extra' which Rosalba sees in her. Just like Rosalba's sons, Nic and Salvo, so Rosalba and Grazia are very different from each other. However, unlike the two men who do not see any value in, and have any respect for, each other's difference, Rosalba and Grazia see each other's difference as a means of learning new ways of being in the world and to re-invent themselves.

According to Colombo, “a journey towards reclaiming one's name - and therefore one's self - seems to be the purpose of all Soldini's filmography" (2002:50). ${ }^{12}$ It is only with the help of another woman that Soldini's female characters find the strength to reclaim their names and

11 "[U]na sapienza che ad alcuni manca, tanto è vero che finiscono per cercare di regolare la piccola parte di mondo dove sono con protocolli e norme formali. Dimenticano così i legami che ognuno di noi ha con sè, con gli altri, col lavoro, con il proprio ambiente."

12 "Un viaggio verso la riconquista del nome - e quindi di se stessi - sembra essere l'approdo di tutta la filmografia Soldini." 
therefore their identities. In Le acrobate, for instance, "the journey ends and the film concludes at the moment in which each of the characters pronounces the name of the other: 'Elena!' 'Yes, Maria?'" (Colombo, 2002:52). ${ }^{13}$

In their theorization of nomadism, Deleuze and Guattari discuss the function of an imaginary Other that remains marginalized and romanticized. For them, however, this Other is "an imaginary space, rather than the location of theoretical production itself" and, therefore, the use of this concept "perpetuates a kind of colonial discourse in the name of progressive politics" (Kaplan, 1996:88). In Soldini's films, on the other hand, the imaginary Other is conceived as "that something extra" embodied in difference. Like the imaginary Other proposed by Deleuze and Guattari, the Other in Soldini's films is romanticized by her difference and it is the desire to comprehend this difference from oneself that drives the formation of a relationship of affidamento. This characterizes the relationship of Anita with regard to Elena, Grazia to Rosalba, and Elena to Teresa. For Teresa, Elena is 'la signora del nord' ('the lady from the North'), a mythic place where she had never been and where she wished to go to leave her tooth. Elena is like a fairy who can turn dreams into reality.

\section{Mirrors and Spectators}

As a director who relates stories through female protagonists, Soldini demonstrates a particular capacity to see things from alternative points-ofview. The cinema of Soldini is characterised by shots featuring reflective

13 "Il viaggio si conclude e il film trova le sue ultime parole nel momento in cui ognuna delle | protagoniste_pronuncia il nome dell'altra: 'Elena!' 'Si, Maria?"” 
surfaces such as train windows, car windscreens and the windows of houses. These reflective surfaces may be considered as types of mirrors, and the recurrent use of them as an invitation to the spectator to view things in other ways rather than on face value. For example, Piazza San Marco and the Grand Canal in Venice are not presented using direct shots but as reflections in Rosalba's sunglasses, in the window of a ferry and on the glass door of an office. It is interesting to note that the office door features the word, 'exchange', as if, in this scene Soldini is inviting his audience to exchange the way in which they perceive and consequently consider things. Soldini invites the audience to look beyond the Venice so well-known to the tourist and consider the lesser-known reality of the city, "la Venezia dei Veneziani" ("the Venice of the Venetians") (Ferrucci, 2000:7) that Rosalba gets to know.

The symbolic mother, or the 'other' woman, with whom Soldini's female characters have a relationship of affidamento, also acts like a mirror - a feminine mirror similar to that which Luce Irigaray calls "a concave speculum" (1985:134). The other woman offers the protagonist a different perspective and another way of being, of seeing and of being seen. Soldini invites his audience to look beyond the surface and search for the "boundless, the indefinable, the unknown" (Schutte, 1991:69).

As already stated, Mulvey considers the cinematic woman to be a construction for consumption by the masculine gaze. She maintains that the provocative way in which the woman is presented is the result of an ideology which interprets sexual difference on the basis of the lack of the penis. As she states:

Woman then stands in patriarchal culture as signifier for the male other, bound by a symbolic order in which man can live 
out his fantasies and obsessions through linguistic command by imposing them on the silent image of woman still tied to her place as bearer of meaning, not maker of meaning. (1988:58)

Mulvey concludes that the form and way in which film texts are presented presumes a male spectator, thus effectively negating the possible presence of a female spectator. De Laurentis arrives at a similar conclusion, arguing that:

[r]epresented as the negative term of sexual differentiation, spectacle-fetish or specular image, in any case obscene, woman is constituted as the ground of representation, the looking-glass held up to man. (1984:15)

In this description of woman as a "looking glass held up to man", sexual difference is exclusively based on biological difference. Furthermore, it implies that all spectators are male and this renders problematic the identification by female spectators with female protagonists.

The construction and subjective representation of female protagonists by Soldini, on the other hand, demonstrates an acknowledgment of the presence of female spectators and allows for their identification with the protagonists. The female spectator, mirroring Soldini's female protagonists who form relationships of affidamento with each other, is able to identify with the protagonists and form a similar relationship of affidamento with the women represented on the screen. If affidamento is "stare nel mondo attraverso la mediazione di un'altra donna" ("being in the world through the mediation of another woman" Franco, 1987:153) from whom you can learn and develop another comprehension of the world, then this substantiates the possibility that even the female spectator 
can form a relationship - albeit only in her mind — with the protagonist. The spectator can consider the protagonist a figure from whom she can learn something, and thus involuntarily forms a relationship with her. The screen in this way functions as a mirror and, for the spectator, the protagonist becomes a representation of the other. Through the use of close-ups, Soldini invites the spectator to form a relationship of affidamento with the protagonist, or more precisely, with the remembered image of the protagonist.

There is, however, a distinction between the image of the protagonist as presented on screen and the perceived image of the protagonist formed by the spectator, which may be called the fantasy image. This fantasy image is formed after the protagonist has been 'read' by the spectator, both during and after the film. It is a metaphorical extension of the representation of the protagonist as presented on screen, and is intrinsically conceived from the spectator's interpretation of the screen image. The spectator recognizes that in reality all images of the protagonist are products of fiction, however despite this she can still create a relationship of affidamento with the protagonist. It is the desire to seek an appropriate woman with whom a relationship of affidamento can be formed that drives the creation of such a relationship. In Le acrobate and Pane e tulipani, this desire is linked to the motif of the journey and the protagonists' unconscious drive to take advantage of chance happenings, or casoalità.

As early as the 1970s, the feminist philosopher Carla Lonzi argued in favour of a theory of sexual difference and in 1984 Irigaray claimed that "la differenza sessuale rappresenta uno dei problemi o il problema che la nostra epoca ha da pensare" ("sexual difference is one of the problems or the problem which our age has to consider" Diotima, 1987:9). In 
collaboration with his scriptwriter, Doriana Leondeff, Soldini joins the many Italian feminist intellectuals who have taken up the challenge of theorising sexual difference as "a difference in symbolisation, a different production of reference and meaning out of a particular embodied knowledge" (Milan Women's Bookshop Collective, 1990:27).

Soldini's emphasis on relationships between female protagonists in his films, and between spectators and characters, illustrates such an understanding of sexual difference and foregrounds the fact that the sociopolitical changes affecting the roles of women in Italian society need to be validated. As theorised by Irigaray and Muraro, this means acknowledging the symbolic order of the mother and, in our view, this acknowledgment of a different symbolic order is what distinguishes Soldini's cinema and makes him an integral part of the new Italian cinema.

(Monash University)

\section{References:}

Audino, E \& $2000 \quad$ Silvio Soldini. Roma: Dino Audino Editore

Medosi, F (eds.)

Braidotti, R.

1994 Nomadic Subjects: Embodiment and Sexual Difference in Contemporary Feminist Theory. New York: Columbia University Press.

Bruno, G \&

1988 Off Screen: Women and film in Italy. Nadotti, M. (eds.) London: Routledge. 
Canova, G.

Carrano, $\mathrm{P}$.

Cavarero, A.

Colombo, S.

De Lauretis, $\mathrm{T}$.

Di Nicola, G.P.

Diotima (ed.)

Dominijanni, I.
1999 L'occhio che ride: Commedia e anticommedia nel cinema italiano contemporaneo. Milano: Editoriale Modo srl.

1977 Malafemmina: La donna nel cinema italiano. Florence: Guaraldi Editore.

1987 Per una teoria della differenza sessuale. In: Diotima. (ed.) Diotima: Il pensiero della differenza sessuale. Milano: La Tartaruga Edizioni: 43-79.

2002 Il cinema di Silvio Soldini. Alessandria: Edizioni Falsopiano.

1984 Alice Doesn't: Feminism, Semiotics, Cinema. Bloomington: Indiana University Press.

1998 Donna agente di cambiamento. In: Ossi, M. (ed.) Donne e cinema nell'Europa duemila: fra immaginario e quotidianità. Colledara: Andromeda Editrice: 109-146.

1987 Il pensiero della differenza sessuale. Milan: La Tartaruga Edizioni.

2003 "Re-thinking Freedom: The Politics of Sexual Difference in contemporary Italy" unpublished paper delivered at Monash University, Melbourne, 22 October, 2003. 
Ferrucci, R. (ed.) $2000 \quad$ Pane e tulipani. Screnplay by Silvio Soldini and Doriana Leondeff. Venezia: Marsilio Editori.

Frabotta, A.

1980 Per una nuova storia della donna nel cinema italiano. In: Incontri Internazionali d'Arte, Roma Filmstudio 70 Politecnico cinema (ed.) Kinomata: La donna nel cinema. Bari: Dedalo libri: 75-83.

Franco, E.

1987 L'affidamento nel rapporto pedagogico. In: Diotima. (ed.) Diotima: Il pensiero della differenza sessuale. Milano: La Tartaruga Edizioni: 153-174.

Gieri, M.

1995 Contemporary Italian Filmmaking: Strategies of Subversion Pirandello, Fellini, Scola, and the Directors of the New Generation. Canada: University of Toronto Press Incorporated.

Gieri, M.

1999 Landscapes of Oblivion and Historical Memory in the New Italian Cinema. Annali d'Italianistica, 17: 39-54.

Grignaffini, G. 2002 La scena madre: scritti sul cinema. Bologna: Bononia University Press.

Irigaray, L. 1985 Speculum of the Other Woman. Trans.G. Gill Ithaca: Cornell University Press. 

Kaplan, C. 1996 Questions of Travel: Post-modern Discourses of Displacement. Durham: Duke University Press.

Laderman, D. 2002 Driving Visions: Exploring the Road Movie. Texas: University of Texas Press.

Landy, M.

2000 Italian Film. United States: Cambridge University Press.

Luciano, B. $\quad 2000$ Rethinking Identity in the Cinema of Silvio Soldini. Forum for Modern Language Studies, 38(3): 341-351.

Malanga, P. (ed.) 1998 Silvio Soldini: Nella città dell'anima. Milano: Città di Savignano sul Rubicone; Assessorato alla Cultura; Centro Culturale di Palazzo Vendemini.

Marcus, M. 2002 After Fellini: National Cinema in the Postmodern Age. Baltimore: The Johns Hopkins University Press.

Milan Women's 1983 "Più donne che uomini." Sottosopra. January 1983. Trans. Bookshop Collective R. Delmar. 1-15.

Milan Women's 1990 Sexual Difference: A Theory of SocialSimbolic Practice. Bookshop Collective. Trans. T. de Lauretis and P. Cicogna. United States: Indiana University Press. 
Mulvey, L.

Muraro, L.

Pilz, K.

Riscaroli, L.

Zamboni, C.
1988 Visual Pleasure and Narrative Cinema. In: Penley, C. (ed.) Feminism and Film Theory. New York: Routledge, Chapman and Hall, Inc: 57-68.

1996 Partire da sé e non farsi trovare... In: Diotima (ed.) La sapienza di partire da sé. Napoli: Liguori Editore: 5-21.

2003 Dreams of Escape: Variations of the Italian Road Movie. Romance Studies, 21(2): 139152.

2003 New Voyages to Italy. Postmodern Travellers and the Italian Road Movie. Screen, 44(1): 71-91.

1991 Irigaray on the Problem of Subjectivity. Hypatia, 6(2): 64-76.

1996 Il materialismo dell'anima. In: Diotima (ed.) La sapienza di partire da sé. Napoli: Liguori Editore: 155-170. 